Tersedia online di: http://ejournal-balitbang.kkp.go.id/index.php/ira

\title{
PERFORMA PEMBESARAN IKAN MAS RAJADANU (Cyprinus carpio) GENERASI KETIGA HASIL SELEKSI "WALKBACK"
}

\author{
Yogi Himawan\#, Khairul Syahputra, dan Didik Ariyanto
}

Balai Riset Pemuliaan Ikan

(Naskah diterima: 21 November 2016; Revisi final: 6 September 2017; Disetujui publikasi: 6 September 2017)

\begin{abstract}
ABSTRAK
Timbulnya wabah penyakit KHV (Koi herpesvirus) pada budidaya ikan mas telah menurunkan produksi ikan mas nasional secara signifikan. Beberapa langkah dilakukan untuk mengatasi penyakit tersebut, salah satunya pembentukan ikan mas Rajadanu tahan KHV melalui seleksi. Dalam rangka memperoleh varietas unggul ikan mas tahan KHV pada tahun 2014 telah dilakukan pembentukan populasi F-3 melalui program selective breeding dengan metode walkback selection. Tujuan penelitian ini adalah menganalisis performa pertumbuhan ikan mas Rajadanu generasi ketiga hasil seleksi melalui uji skala lapang pada fase pembesaran, serta kegiatan uji tantang pada skala laboratorium. Benih F-3 merupakan hasil pemijahan F-1 betina dan F2 jantan hasil seleksi positif MHC (Major Histocompatibility Complex), sedangkan kontrol berupa benih ikan mas Majalaya dari pembudidaya, masing-masing tiga ulangan. Uji tantang KHV dilakukan di akuarium berukuran $60 \mathrm{~cm} \times 40 \mathrm{~cm} \times 40 \mathrm{~cm}$ di hatchery ikan mas dengan suhu permissive $21^{\circ} \mathrm{C}$ melalui metode kohabitasi. Hasil penelitian menunjukkan bahwa populasi F-3 ikan mas Rajadanu hasil seleksi memiliki performa pertumbuhan relatif lebih baik 6,20\%dibandingkan dengan kontrol pada karakter panjang total $(18,14 \pm 4,90 \mathrm{~cm}), 5,80 \%$ lebih baik pada karakter panjang standar $(14,76 \pm 4,39 \mathrm{~cm}) ; 38,39 \%$ lebih baik pada karakter bobot rata-rata $(393,98 \pm 3,53 \mathrm{~g}) ; 16,83 \%$ pada karakter laju pertumbuhan spesifik $(2,29 \pm$ 0,04\%; dan 3,80\% pada karakter sintasan $(49,13 \pm 6,88 \%$. Hasil uji tantang KHV menunjukkan sintasan populasi F-3 lebih tinggi $(96,6 \pm 3,3 \%$ dibandingkan dengan kontrol $(51,1 \pm 8,3 \%$.
\end{abstract}

\section{KATA KUNCl: ikan mas; KHV; uji tantang; pertumbuhan; sintasan}

ABSTRACT: Performance of F-3 rajadanu carp (Cyprinus carpio) resulted by walkback selection in growthout. By: Yogi Himawan, Khairul Syahputra, and Didik Ariyanto

The outbreaks of KHV (Koi herpesvirus) disease in carp culture have significantly reduced Indonesia's national carp production. Several strategies have been devised to combat the outbreaks including the development of KHV resistant carp varieties such as selective carp breeding program in 2014. The purpose of this study was to analyze the growth performance of the third generation (F-3) Rajadanu through field-scale test (grow out) and challenge test (laboratoryscale). The study was designed in a completely randomized design with two treatments (F-3 populations) and carp seed from the local small-scale fish farmers as control, each with three replicates. F-3 seed was produced from spawning between F-1 females and F-2 males which had a Major Histocompatibility Complex positive selection. The challenge test was carried out in the aquarium sized $60 \mathrm{~cm} \times 40 \mathrm{~cm} \times 40 \mathrm{~cm}$ at the hatchery with the permissive temperature of $21^{\circ} \mathrm{C}$. The results showed that F-3 Rajadanu population had relatively higher total length $(18.14 \pm 4.90 \mathrm{~cm})$ of $6.20 \%$ standard length $(14.76 \pm 4.39 \mathrm{~cm})$ of $5.80 \%$ weight average $(393.98 \pm 3.53 \mathrm{~g})$ of $38.39 \%$ specific growth rate $(2.29 \pm 0.04 \%$ of $16.83 \%$ and survival rate $(49.13 \pm 6.88 \%)$ of $3.80 \%$ than that of control population. The result of the challenge test on KHV in the laboratory showed that F-3 population had higher survival rate (96.6 \pm $3.3 \%$ compared to that of control $(51.1 \pm 8.3 \%$.

\section{KEYWORDS: carp; KHV; challenge test; growth rate; survival rate}

\section{PENDAHULUAN}

Ikan mas merupakan salah satu komoditas ikan air tawar yang populer dibudidayakan khususnya di wilayah

\# Korespondensi: Balai Riset Pemuliaan Ikan. Jl. Raya Sukamandi No. 2, Subang 41256, Indonesia.

Tel. + (0251) 8313200

E-mail: yogihimawan@yahoo.com
Sumatera, Jawa, Nusa Tenggara, dan Kalimantan. Khusus di Jawa Barat, ikan mas merupakan salah satu komoditas andalan dalam kegiatan budidaya baik di kolam air tenang (KAT), kolam air deras (KAD), dan karamba jaring apung (KJA). Namun demikian, timbulnya wabah penyakit yang disebabkan oleh virus (Koi Herves Virus, KHV) pada sekitar tahun 2002 
membuat usaha budidaya ikan mas mengalami penurunan yang sangat drastis. Hal tersebut juga mengakibatkan sebagian besar pembudidaya ikan mas di beberapa sentra produksi beralih ke komoditas lainnya. Koi herpesvirus ditemukan pertama kali pada tahun 1998 yang menyebabkan kematian massal pada ikan mas budidaya di Israel dan USA (Gilad et al., 2002). Virus ini masuk ke Indonesia pada tahun 2002 melalui perdagangan ikan koi. Adapun sejarah penyebaran wabah KHV di Indonesia seperti yang telah digambarkan oleh Sunarto et al. (2005) bahwa serangan pertama kali penyakit tersebut telah mengakibatkan terjadinya kematian massal pada ikan Koi pada bulan Maret 2002 di Blitar, Jawa Timur.

Beberapa upaya telah dilakukan untuk menanggulangi berkembangnya penyakit KHV seperti penggunaan benih yang bebas KHV, peningkatan imunitas ikan sampai dengan perbaikan teknologi budidaya. Selain upaya tersebut di atas, penanggulangan penyakit ini dapat dilakukan dengan pendekatan secara genetik. Pendekatan secara genetik dapat dilakukan melalui dua cara, yaitu secara konvensional antara lain melalui kegiatan seleksi atau hibridisasi dan secara modern antara lain melalui pendekatan genetika molekuler. Metode lain yang dapat diterapkan adalah melalui penggabungan metode konvensional dan modern seperti seleksi menggunakan atau berdasarkan pada marka yang bersifat molekuler. Menurut Pang et al. (2013), metode seleksi genetik marker assisted selection (MAS) dapat digunakan untuk menghasilkan ikan yang resisten terhadap penyakit.

Dalam rangka penanggulangan penyakit tersebut, pada tahun 2010 Balai Penelitian Pemuliaan Ikan (BPPI) memulai kegiatan perakitan varietas unggul tahan KHV. Kegiatan dimulai dengan koleksi plasma nutfah ikan mas yang berpotensi untuk dikembangkan melalui program tersebut (Ariyanto et al., 2010a). Hasil evaluasi daya tahan populasi plasma nutfah ikan mas hasil koleksi terhadap KHV menunjukkan bahwa strain Rajadanu mempunyai daya tahan terhadap KHV relatif lebih baik dibanding strain lainnya (Ariyanto et al., 2010b). Berdasarkan hasil evaluasi tersebut, dibentuk populasi dasar ( $\mathrm{F}-0$ ) ikan mas strain Rajadanu sebagai bahan dasar pembentukan ikan mas tahan KHV (Ariyanto et al., 2010c). Pada tahun 2011, populasi dasar ini diseleksi menggunakan metode tandem selection untuk mendapatkan populasi tahan terhadap $\mathrm{KHV}$ dengan laju pertumbuhan cepat (Ariyanto et al., 2011). Pada tahun 2013 dilakukan pembentukan calon induk populasi $\mathrm{F}-2$, hasil pemijahan back-cross induk jantan F-1 terseleksi dengan induk betina F-0 terseleksi. Selective breeding menggunakan metode walkback selection ini mengikuti pola yang dilakukan oleh Macbeth \& Palmer (2011). Pada tahun 2013 juga dilakukan evaluasi keragaan benih F-2 meliputi keragaan genetika molekuler, uji daya tahan secara laboratorium, serta keragaan benih pada kegiatan budidaya skala lapang. Pada tahun 2014 kegiatan seleksi ikan mas Rajadanu tahan KHV sudah mencapai generasi ketiga (F-3) dan seperti halnya tahun sebelumnya kegiatan lanjutan setelah terbentuknya $F$ 3 adalah uji performa di lapangan dan uji tantang di laboratorium. Berdasarkan hal tersebut, secara khusus tujuan penelitian ini adalah mengevaluasi performa benih ikan mas generasi ketiga ( $F-3$ ) hasil seleksi pada fase pembesaran di kolam pengujian dan menguji tantang pada skala laboratorium di hatchery Balai Penelitian Pemuliaan Ikan (BPPI) Sukamandi.

\section{BAHAN DAN METODE}

\section{Penyediaan Benih}

Benih ikan mas Rajadanu F-3 yang digunakan merupakan hasil pemijahan dari induk F-2 jantan hasil seleksi berdasarkan bobot dengan induk F-1 betina yang diseleksi berdasarkan karakter ketahanan terhadap penyakit menggunakan marka molekuler Major histocompatibility complex (MHC) melalui metode PCR. MHC merupakan genom terbesar yang dapat ditemukan pada vertebrata yang mengkode molekul yang berperan penting dalam sistem kekebalan tubuh (Zhou et al., 2013). Beberapa studi menunjukkan bahwa ekspresi gen MHC berasosiasi dengan resistensi terhadap patogen pada ikan ciprinid (Rakus et al., 2009). Pemijahan menggunakan metode pemijahan buatan dengan bantuan hormon HCG (Human Chorionic Gonadotropin) yang disuntik secara intra muscular pada bagian punggung (Harvey \& Carolsfeld, 1993). HCG merupakan jenis hormon yang umum digunakan untuk menstimulasi ovulasi pada ikan (Park, 2002). HCG terbukti mampu menginduksi ovulasi beberapa spesies ikan antara lain channel catfish (Ictalurus punctatus), ikan mas koki (Carassius auratus), dan striped bass (Morone saxatilis). Pelaksanaan kegiatan seleksi pertumbuhan pada karakter bobot mengikuti protokol seleksi within family dengan mengacu pada metode seleksi menurut Tave (1993; 1996). Populasi calon induk F-2 hasil seleksi berdasarkan karakter pertumbuhan dan daya tahan terhadap KHV yang diperoleh pada tahun 2013, dipelihara sesuai dengan SOP pemeliharaan calon induk secara optimal. Setelah mencapai usia reproduksi, induk dipijahkan untuk mendapatkan generasi F-3 dari 25 famili. Populasi F-3 dipelihara sampai umur tiga bulan hingga mencapai bobot 10-12 g/ekor. Populasi ikan kontrol didapatkan dari pembudidaya di sekitar wilayah Sukamandi yang didominasi petani pendeder ikan mas Majalaya dengan bobot rata-rata $10 \mathrm{~g} / \mathrm{ekor}$. 


\section{Uji Performa}

Lokasi yang digunakan untuk pengujian adalah kolam pengujian BPPI berukuran $50 \mathrm{~m}^{2}$ berdinding beton dan dasar kolam lumpur. Bahan uji pada lokasi percobaan terdiri atas 2 populasi benih ikan mas, yaitu (A) benih ikan mas F-3 hasil seleksi dan (B) kontrol berupa benih ikan mas Majalaya dari UPR yang yang biasa digunakan untuk kegiatan budidaya di masyarakat. Pada pengujian digunakan enam unit kolam ukuran $50 \mathrm{~m}^{2}$ dengan padat tebar $10 \mathrm{ekor} / \mathrm{m}^{2}$. Pengujian dilakukan selama tiga bulan. Pemberian pakan berupa pelet komersial dengan kandungan protein $30 \% 32 \%$ dilakukan dua kali sehari. Tiap kolam dilengkapi sirkulasi air untuk mempertahankan kualitas air media pemeliharaan. Sampling pada parameter panjang total, panjang standar, dan bobot rata-rata individu dilakukan sebanyak 50 ekor tiap kolam setiap bulannya hingga akhir masa pemeliharaan untuk mengetahui performa pertumbuhannya.

\section{Uji Tantang di Laboratorium}

Tahapan pertama dalam melakukan kegiatan uji tantang adalah dengan mempersiapkan ikan uji yang merupakan populasi benih F-3 dari induk-induk terseleksi. Selanjutnya mempersiapkan ikan sumber KHV dan wadah penelitian berupa akuarium. Ikan sumber merupakan ikan pembawa KHV yang akan menularkan virus tersebut kepada ikan uji. Ikan sumber memiliki ukuran sama dengan ikan uji dan dipelihara bersama sebanyak $10 \%$ dari jumlah ikan uji. Pembuatan ikan sumber melalui penyuntikan filtrat KHV sebanyak 0,1 mL/ekor secara intramuscular kemudian dipelihara dan diamati hingga timbul gejala klinis serangan KHV. Setelah gejala klinis terlihat maka dilanjutkan dengan uji KHV untuk memastikan bahwa ikan sumber telah terjangkit penyakit tersebut. Prosedur uji tantang yang dilakukan sesuai yang tercantum dalam protokol pemuliaan ikan mas uji tantang dilakukan pada akuarium berukuran $60 \mathrm{~cm} x$ $40 \mathrm{~cm} \times 40 \mathrm{~cm}$, diisi 30 ekor ikan uji/akuarium ditambah ikan terinfeksi KHV sebanyak 10\%dari jumlah total ikan. Ukuran ikan yang digunakan 10-12 g/ekor dengan padat penebaran dalam satu akuarium adalah 1 ekor/liter air. Terdapat dua jenis ikan mas yang akan diuji di antaranya, A: ikan mas F-3 hasil seleksi, B: kontrol berupa Ikan mas dari UPR. Perlakuan dilakukan dengan ulangan sebanyak tiga kali. Sebelum uji tantang dilakukan, ikan uji diaklimatisasi terlebih dahulu pada suhu rendah sekitar $21^{\circ} \mathrm{C}-22^{\circ} \mathrm{C}$ selama $1-2$ hari. Selanjutnya diuji tantang dengan KHV menggunakan metode kohabitasi. Uji tantang dilakukan di dalam laboratorium yang tertutup dengan suhu ruangan dikondisikan pada kisaran $21^{\circ} \mathrm{C}-23^{\circ} \mathrm{C}$ untuk mendapatkan suhu yang permisif bagi berkembangnya virus KHV. Uji tantang dilakukan selama 21 hari pemeliharaan.

\section{Deteksi KHV dengan Metode PCR}

Ikan yang mengalami kematian dari tiap populasi dilakukan pengujian di laboratorium menggunakan metode PCR untuk memastikan penyebab kematian ikan tersebut memang disebabkan KHV, bukan karena faktor lingkungan atau teknis pemeliharaan. Deteksi KHV dilakukan pada ikan sebelum diuji tantang, ikan yang diduga terserang KHV, dan ikan pada akhir percobaan. Organ yang diambil sebagai sampel adalah insang, selanjutnya di isolasi DNA. Setelah memperoleh Genom DNA dilakukan PCR dengan menggunakan primer SPHL-5 (Gray et al., 2002), dengan susunan basa sebagai berikut:

Referse: 5'GACACATGTTACAATGGTCGC-3

Foward: 5'GACACCACATCTGCAAGGAG-3 dengan panjang fragmen $292 \mathrm{bp}$.

Pengukuran kualitas air di lapangan dilakukan secara in situ meliputi suhu, oksigen terlarut, $\mathrm{pH}$, dan informasi geografi di areal kolam pengujian Sukamandi untuk mengetahui kondisi media pemeliharaan sebagai data dukung. Analisis data hasil penelitian menggunakan analisis Chi-Square untuk mengetahui perbedaan antar perlakuan.

\section{HASIL DAN BAHASAN}

Keragaan fenotipik diperoleh pada masing-masing populasi ikan mas yang dipelihara selama tiga bulan di kolam pengujian Sukamandi memperlihatkan bahwa populasi ikan mas hasil seleksi mempunyai rata-rata panjang standar, panjang total dan bobot badan individu lebih baik dibanding benih ikan mas dari UPR. Hasil kegiatan uji performa menunjukkan populasi F3 ikan mas Rajadanu memiliki laju pertumbuhan panjang total, panjang standar, bobot rata-rata individu, serta nilai konversi pakan relatif lebih baik dibanding populasi kontrol (Tabel 1).

Hasil analisis Chi-Square pada karakter bobot menunjukkan adanya perbedaan (Asymp.Sig < 0,05), sehingga $\mathrm{H}-\mathrm{O}$ ditolak dan $\mathrm{H}-1$ diterima maka kesimpulan yang didapat adalah terdapat perbedaan pertumbuhan bo bot antara populasi F-3 dibandingkan UPR. Selain itu, nilai standar deviasi pada rata-rata bobot individu populasi ikan mas hasil seleksi lebih rendah dibanding pada populasi ikan mas dari UPR (Tabel 1). Hasil ini menunjukkan bahwa populasi ikan mas hasil seleksi mempunyai tingkat keseragaman lebih tinggi antar individu. Dengan kata lain ukuran individu-individu dalam populasi ikan mas hasil seleksi lebih seragam dibanding populasi benih dari UPR. Kondisi ini diduga karena adanya aktivitas seleksi yang 
Tabel 1. Panjang total, panjang standar, bobot badan, dan nilai konversi pakan benih ikan mas yang dipelihara selama tiga bulan di kolam pengujian Sukamandi

Table 1. Total length, standard length, body weight, and feed conversion ratio of fieldscale test carp population cultured in Sukamandi ponds for three months

\begin{tabular}{lc}
\hline \multicolumn{1}{c}{ Karakter (Trait) } & Nilai Nalue) \\
\hline Panjang total (Total length) (cm) & \\
- Populasi F-3 (F-3 population) & $18.14 \pm 4.90$ \\
- Populasi kontrol (Control population) & $17.08 \pm 4.40$ \\
\hline Panjang standar (Standart length) (cm) & \\
- Populasi F-3 (F-3 population) & $14.76 \pm 4.39$ \\
- Populasi kontrol (Control population) & $13.95 \pm 3.62$ \\
\hline Bobot rata-rata (Average body weight) (g) & \\
- Populasi F-3 (F-3 population) & $393.98 \pm 3.53$ \\
- Populasi kontrol (Control population) & $284.68 \pm 6.00$ \\
\hline Konversi pakan (Feed convertion ratio) (FCR) & \\
- Populasi F-3 (F-3 population) & 2.35 \\
- Populasi kontrol (Control population) & 3.29 \\
\hline
\end{tabular}

dilakukan pada strain ikan mas Rajadanu sehingga keseragaman fenotopik dapat terjaga. Seleksi tidak menciptakan gen baru, tetapi dapat mengubah frekuensi alel-alel tertentu untuk mendapatkan penampilan fenotipik yang diharapkan, misalnya laju pertumbuhan cepat, daya tahan terhadap penyakit atau lingkungan, fekunditas tinggi, dan lain-lain (Falconer \& Mackay, 1996; Tave, 1996; Warwick et al., 1995, Hardjosubroto, 1994). Hasil analisis nilai konversi pakan pada pemeliharaan di kolam berukuran $50 \mathrm{~m}^{2}$ berdinding beton dan dasar berlumpur menunjukkan populasi F-3 memiliki kemampuan mengubah pakan menjadi daging lebih baik dibanding kontrol. Menurut Kusriani et al. (2012), rasio konversi pakan bisa diartikan perbandingan jumlah pakan yang diberikan terhadap bobot ikan akhir ditambah bobot total ikan yang mati dikurangi bobot ikan awal atau pertambahan bobot yang dihasilkan. Dalam hal ini semakin kecil nilai konversi pakan maka kemampuan ikan untuk merubah pakan menjadi daging akan semakin baik. Konversi pakan sebesar 2,35 untuk populasi F-3 menunjukkan bahwa dibutuhkan sebanyak $2,35 \mathrm{Kg}$ pakan untuk menghasilkan peningkatan bobot ikan sebesar $1 \mathrm{~kg}$, sedangkan populasi kontrol membutuhkan jumlah pakan lebih besar yakni $3,29 \mathrm{~kg}$ pakan untuk menghasilkan $1 \mathrm{~kg}$ daging. Menurut Yudiarto et al. (2012), efisiensi pakan menunjukkan seberapa besar pakan yang dapat dimanfaatkan oleh ikan. Konversi dan efisiensi pakan juga erat hubungannya dengan nilai kecernaan yang menggambarkan persentase nutrien yang dapat diserap oleh saluran pencernaan tubuh ikan. Semakin besar nilai kecernaan suatu pakan maka semakin banyak nutrien pakan yang dimanfaatkan oleh ikan tersebut. Nutrien yang dimanfaatkan oleh ikan mas dapat memengaruhi penyediaan energi protein dan non-protein dalam tubuh. Menurut Akbar (2002), semakin banyak energi yang tersedia dalam tubuh akan meningkatkan kemampuan ikan mas untuk mengubah energi tersebut dan disimpan dalam bentuk daging.

Hasil pengamatan pada karakter laju pertumbuhan spesifik menunjukkan bahwa populasi F-3 memiliki nilai rata-rata 2,29 $\pm 0,04 \%$ lebih besar dibanding populasi kontrol sebesar 1,96 $\pm 0,05 \%$ (Gambar 1$)$.

Laju pertumbuhan spesifik pada populasi F-3 relatif lebih besar dibanding kontrol diduga karena adanya sumbangan genotipe seleksi yang dilakukan sebelumnya sehingga performa populasi F-3 relatif stabil dan berpengaruh positif terhadap pertumbuhan bobot selama masa pemeliharaan. Tave (1993), Hardjosubroto (1994), Tave (1996), dan Noor (2000) menjelaskan bahwa penampilan fenotipik suatu varietas/genotipe dipengaruhi oleh faktor genetik, lingkungan, serta kemungkinan adanya interaksi antara kedua faktor tersebut. Selain itu, daya adaptasi populasi F-3 terhadap lingkungan budidaya relatif lebih tinggi dibanding kontrol sehingga energi untuk tumbuh tidak terganggu untuk beradaptasi dengan lingkungan budidaya. 


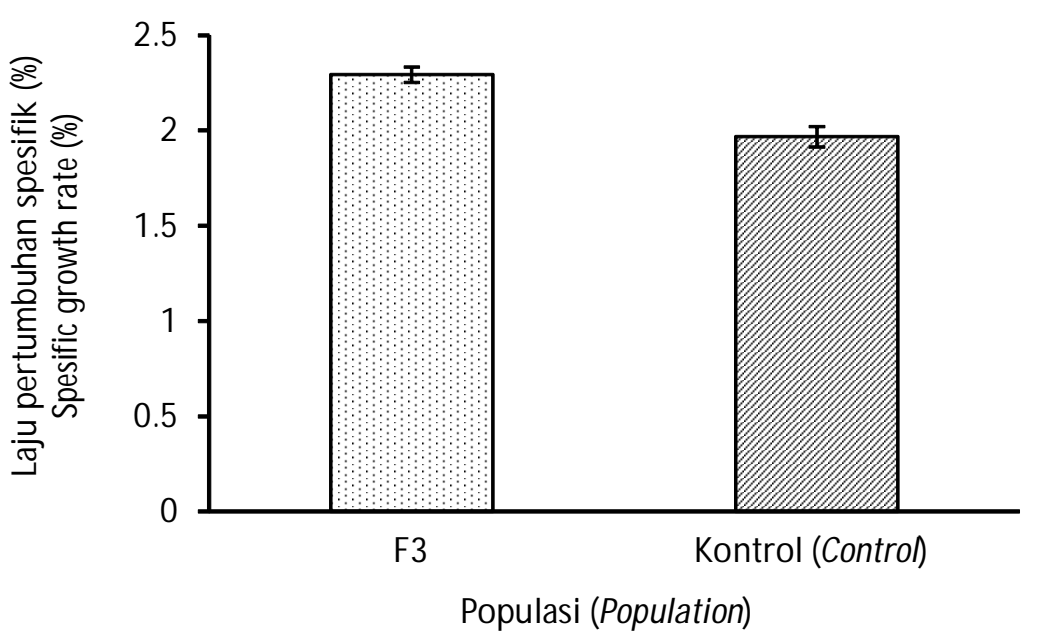

Gambar 1. Laju pertumbuhan spesifik populasi F-3 dan kontrol selama pemeliharaan di kolam pengujian Sukamandi.

Figure 1. Specific growth rate of F-3 population and control during field-scale test in Sukamandi ponds.

Sintasan pada uji dua populasi di kolam BPPI Sukamandi menunjukkan populasi F-3 memiliki sintasan sebesar 49,13 $\pm 6,88 \%$ relatif lebih baik dibanding populasi kontrol yang mencapai $47,33 \pm$ 0,95\%(Gambar 2).

Secara umum, sintasan antar populasi masih menunjukkan nilai rata-rata yang relatif cukup tinggi. Salah satunya diduga karena kepadatan ikan dalam penelitian ini cukup rendah sehingga kompetisi untuk mendapatkan pakan terbilang masih dalam taraf normal. Namun demikian, kemampuan populasi F-3 mempertahankan hidup dengan beradaptasi pada kondisi kolam budidaya dan faktor biotik, serta abiotiknya lebih baik dibanding kontrol sehingga sintasan yang didapat masih lebih tinggi dibanding kontrol. Menurut Effendi (1986), beberapa faktor yang memengaruhi tinggi rendahnya sintasan adalah abiotik dan biotik antara lain kompetitor, kepadatan, populasi, umur, dan kemampuan organisme beradaptasi dengan lingkungannya. Selain itu, nilai sintasan yang tidak

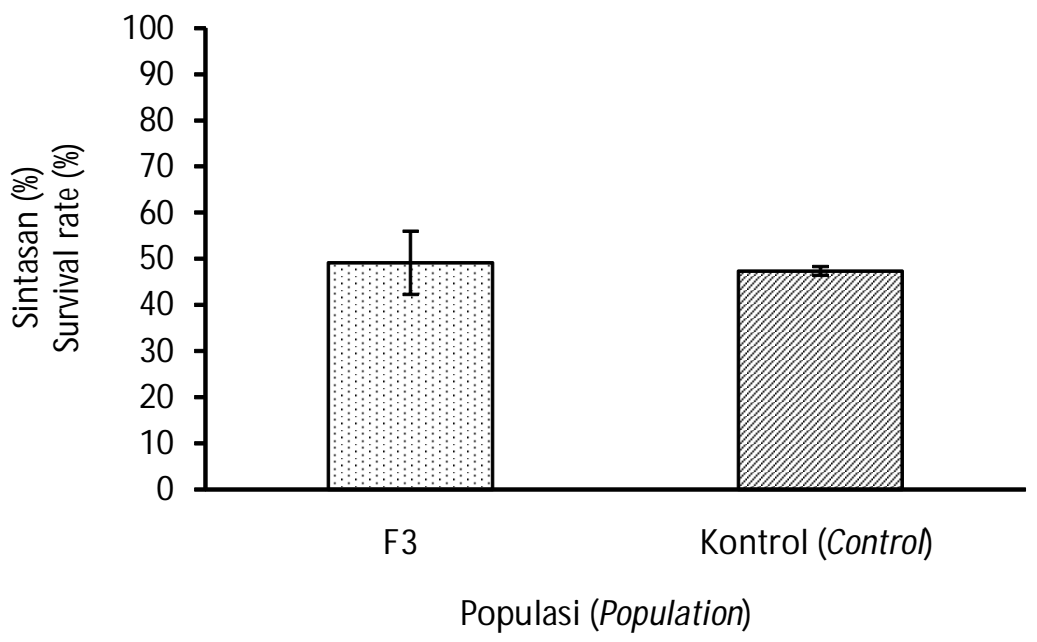

Gambar 2. Sintasan rata-rata populasi F-3 dan kontrol pada kolam pengujian Sukamandi.

Figure 2. Average survival rate of F-3 and control populations during field-scale test in Sukamandi ponds. 
berbeda juga diduga karena pada dasarnya ikan mas Rajadanu F-3 tahan KHV didesain untuk lebih tahan pada kondisi terjadinya serangan virus KHV, sedangkan pada kondisi normal tanpa adanya KHV maka performa sintasannya tidak jauh berbeda dengan ikan mas pada umumnya meskipun masih lebih tinggi nilainya. Keberadaan gen MHC dalam ikan mas Rajadanu F-3 tahan KHV akan sangat membantu dalam hal mempertahankan sintasan ketika KHV mulai aktif menyerang. Hal tersebut diduga terkait dengan ketahan spesifik ikan mas Rajadanu F-3 terhadap serangan KHV. Sistem pertahanan spesifik berfungsi untuk melawan penyakit yang memerlukan rangsangan terlebih dahulu, sementara pertahanan non-spesifik berfungsi untuk pertahanan terhadap patogen dan bersifat permanen (selalu ada) (Ellis, 1988). Sistem pertahanan spesifik memiliki kemampuan mengenali benda yang dianggap asing bagi dirinya. Sistem imun spesifik terdiri atas humoral, selular, dan organ limfoid. MHC termasuk sistem imun spesifik yang bersifat adaptif dan terletak dalam kromosom- 6 , serta berperan dalam pengenalan dan pemberian sinyal di antara sel-sel sistem imun. MHC terdiri atas sel-sel imunokompeten seperti sel B, monosit, makrofag, Antigen Presenting Cells (APC), dan sel $T$ aktif yang terdapat pada epitel kelenjar Timus (Baratawidjaja, 1991; Subowo, 1993).

\section{Uji Tantang}

Hasil uji tantang pada kondisi terakhir memperlihatkan bahwa populasi F-3 memiliki sintasan relatif lebih tinggi yakni sebesar $96,6 \pm 3,3 \%$ dibanding populasi kontrol sebesar $51,1 \pm 8,3 \%$ (Gambar 3 ).

Daya tahan populasi F-3 dibanding kontrol relatif lebih baik diduga pada populasi tersebut telah terjadi peningkatan daya tahan terhadap KHV dibanding generasi sebelumnya, hal tersebut dapat dilihat dari hasil akhir sintasan pada saat diuji coba secara laboratorium dengan suhu permisif. Peningkatan daya tahan populasi F-3 terhadap KHV salah satunya diduga karena adanya unsur seleksi pada populasi tersebut melalui seleksi famili sehingga terjadi peningkatan daya tahan terhadap KHV dibanding populasi kontrol. Adanya peningkatan secara populasi tersebut mengindikasikan transfer daya tahan terhadap KHV antar populasi ikan mas rajadanu hasil seleksi dapat berjalan dengan lancar sehingga diharapkan benih sebar yang akan digunakan masyarakat pun dapat memiliki karakter yang sama. Dalam uji tantang tersebut, populasi yang pertama kali mengalami kematian adalah kontrol pada hari ke-4, sedangkan populasi F-3 baru mengalami kematian pada hari ke-8 sebanyak satu ekor. Trend sintasan ikan mas populasi kontrol terus mengalami penurunan berturut-turut hingga hari ke21 (Gambar 4).

Berdasarkan kondisi selama masa pemeliharaan dapat dikatakan bahwa populasi F-3 mengalami kemajuan positif dalam bertahan dari serangan virus KHV yang diujikan secara kohabitasi dibandingkan populasi kontrol. Hasil anal isis gejala klinis dan analisis laboratorium menunjukkan bahwa kematian pada tiap populasi tidak hanya diakibatkan serangan KHV, namun juga diduga diakibatkan pengaruh media pemeliharaan. Hasil uji laboratorium pada sampel ikan yang mengalami kematian saat uji tantang melalui metode PCR didapatkan 80\% merupakan positif diakibatkan oleh KHV, sedangkan populasi F-3 hanya $60 \%$ sisanya karena faktor lingkungan (Gambar 5). Hasil tersebut memperlihatkan bahwa populasi F-3 lebih mampu

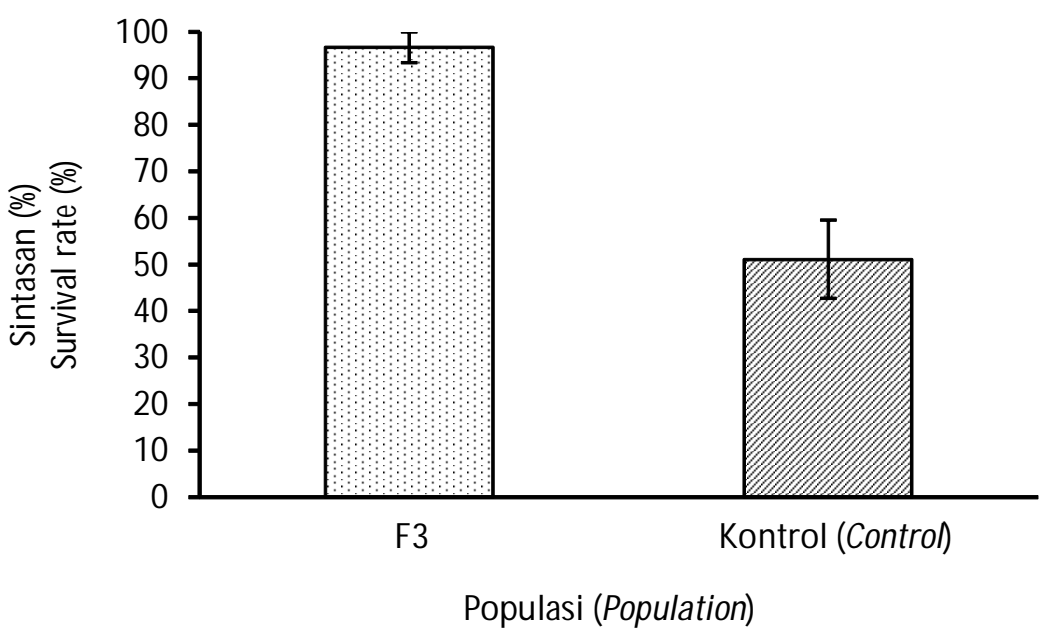

Gambar 3. Sintasan populasi F-3 berdasarkan hasil uji tantang di laboratorium.

Figure 3. Survival rate of F-3 populations in the challenge test in the laboratory. 


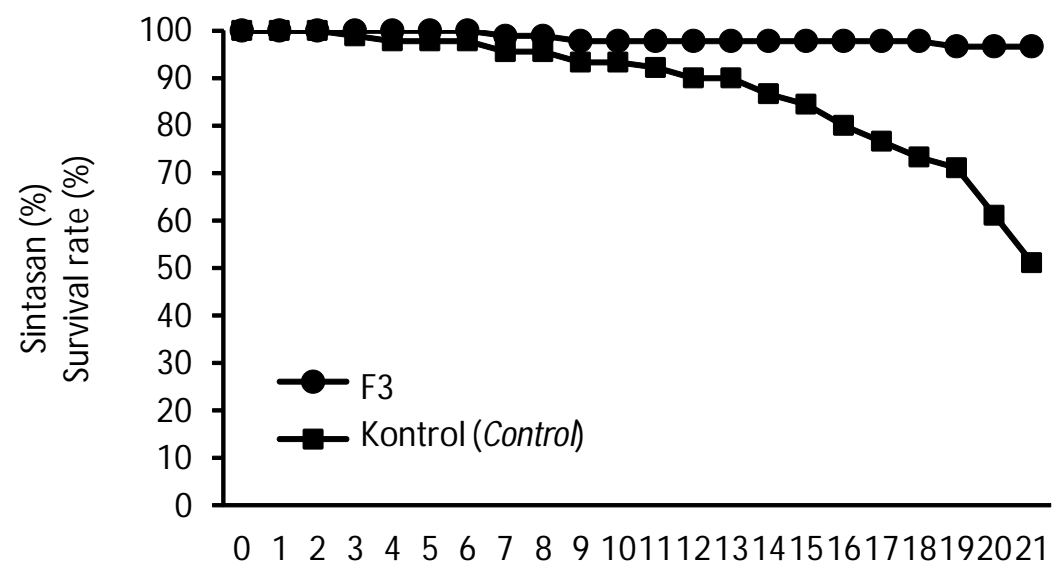

Hari ke- (Days-)

Gambar 4. Penurunan sintasan populasi F-3 dan kontrol eksternal pada uji tantang skala laboratorium selama 21 hari.

Figure 4. Decreasing trend of survival rate of F-3 and control populations during 21 days of laboratory-scale challenge test.

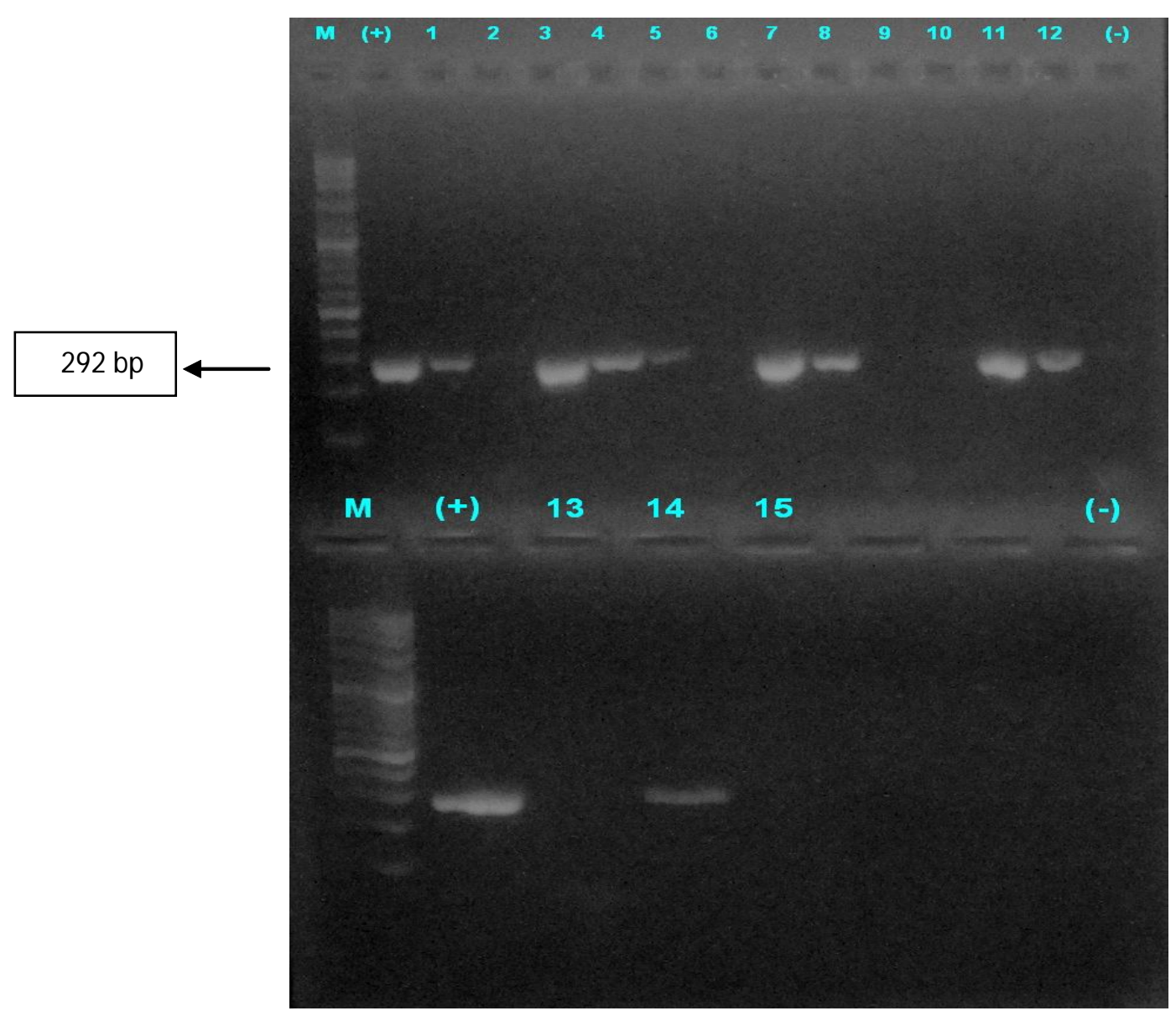

Keterangan: 1-5 adalah populasi kontrol dan 11-15 adalah populasi F3

Gambar 5. Hasil elektroforesis sampel uji tantang KHV pada skala laboratorium.

Figure 5. Results of electrophoresis on sample from KHV challenge test in laboratory-scale. 
mempertahankan diri dari serangan KHV dibanding ikan kontrol sehingga diharapkan pada secara genotipe kondisi tersebut dapat terus dipertahankan.

Hasil pengujian menggunakan metode PCR memperlihatkan bahwa sebanyak $80 \%$ dari sampel ikan kontrol yang mengalami kematian ternyata positif KHV sehingga diduga daya tahan terhadap KHV lebih rendah dibanding populasi F-3 yang mencapai $60 \%$ positif KHV. Daya tahan terhadap KHV dari populasi F-3 diduga karena adanya pengaruh kegiatan seleksi pada generasi sebelumnya sehingga genotipe ketahanan terhadap KHV lebih tinggi dibanding tanpa seleksi.

\section{Kualitas Air}

Secara umum parameter kualitas air masih berada dalam batas normal untuk menunjang kehidupan ikan mas yang diamati (Tabel 2). Kondisi suhu dan pH meskipun berfluktuasi namun masih bisa ditolerir oleh ikan mas sehingga tidak terjadi penurunan sintasan secara signifikan. Namun demikian kondisi parameter yang harus diperhatikan adalah kandungan oksigen terlarut yang mencapai titik rendah di $0,8 \mathrm{mg} / \mathrm{L}$ yang dapat menghambat pertumbuhan karena ikan mas termasuk organisme yang sensitif dengan kandungan oksigen terlarut.

\section{KESIMPULAN}

Populasi F-3 ikan mas Rajadanu hasil seleksi memiliki performa pertumbuhan relatif lebih baik dibanding kontrol eksternal pada karakter panjang standar, panjang total, bobot rata-rata, dan laju pertumbuhan spesifik. Hasil uji tantang terhadap KHV pada skala laboratorium yang lebih terkontrol menunjukkan sintasan populasi F-3 lebih tinggi dibandingkan kontrol eksternal.

\section{UCAPAN TERIMA KASIH}

Naskah ini merupakan bagian dari kegiatan penelitian yang dibiayai APBN melalui DIPA tahun 2014 pada Balai Penelitian Pemuliaan Ikan, Sukamandi. Terima kasih disampaikan kepada semua teknisi lapang yang terlibat dalam kegiatan penelitian ini. Selain itu, terima kasih juga disampaikan kepada semua pihak pembudidaya yang sudah bekerja sama dalam pengujian populasi ikan mas hasil seleksi ini.

Tabel 2. Variasi kualitas air and parameter budidaya selama penelitian

Tabel 2. Water quality measurement and culture parameters of the trial

\begin{tabular}{lc}
\hline \multicolumn{1}{c}{ Parameter (Parameters) } & Kisaran (Range) \\
\hline $\begin{array}{l}\text { Ketinggian (m dpl) } \\
\text { Altitude (m asl)* } \\
\text { Suhu air }\end{array}$ & 16 \\
Water temperature $\left({ }^{\circ} \mathrm{C}\right)$ & $27.2-29.0$ \\
Oksigen terlarut & \\
Dissolved oxygen $(\mathrm{mg} / \mathrm{L})$ & $0.8-3.6$ \\
pH & $7.0-8.0$ \\
Amonia & $0.05-0.24$ \\
Ammonia (mg/L) & \\
Nitrit & $0.001-0.02$ \\
Nitrite (mg/L) & Kolam air tenang \\
Sistem budidaya & Quite water pool \\
Culture system & $10 \times 5$ \\
Ukuran kolam & \\
Pond size (m ${ }^{2}$ ) & \\
Padat tebar (kg/kolam) & 5 \\
Density (kg/pond) & Terapung \\
Jenis pakan & Floating \\
Type of feed &
\end{tabular}

Keterangan (Note): * asl: above sea level 


\section{DAFTAR ACUAN}

Akbar, A.D. (2002). Pengaruh penggantian tepung terigu dengan tepung singkong terhadap efisiensi pakan dan pertumbuhan ikan mas (Cyprinus carpio L). Skripsi. Institut Pertanian Bogotr. Bogor, $43 \mathrm{hlm}$.

Ariyanto, D., Hayuningtyas, E.P., \& Syahputra, K. (2010a). Koleksi dan karakterisasi populasi ikan mas sebagai bahan pembentuk ikan mas tahan KHV. Seminar hasil penelitian LRPTBPAT tahun 2010. Sukamandi, 13-14 Desember 2010.

Ariyanto, D., Hayuningtyas, E.P., \& Syahputra, K. (2010b). Evaluasi daya tahan lima strain ikan mas terhadap KHV. Seminar hasil penelitian LRPTBPAT tahun 2010. Sukamandi, 13-14 Desember 2010.

Ariyanto, D., Hayuningtyas, E.P., \& Syahputra, K. (2010c). Pembentukan populasi dasar ikan mas tahan KHV. Seminar hasil penelitian LRPTBPAT tahun 2010. Sukamandi, 13-14 Desember 2010.

Ariyanto, D., Hayuningtyas, E.P., \& Syahputra, K. (2011). Seleksi karakter pertumbuhan ikan mas tahan KHV. Seminar hasil penelitian BPPI tahun 2011. Sukamandi, 27-28 Desember 2011.

Baratawidjaja, K.G. (1991). Imunologi dasar. Edisi kedua. Fakultas Kedokteran Universitas Indonesia Press. Jakarta, $222 \mathrm{hlm}$.

Effendie, M.I. (1986). Metode biologi perikanan. Bogor: Yayasan Dwi Sri, $112 \mathrm{hlm}$.

Ellis, A.E. (1988). General principles of fish vaccinations. London: Academic Press, p. 1-19.

Falconer, D.S. \& Mackay, T.F.C. (1996). Introduction to quantitative genetics. $4^{\text {th }}$ Ed. Longman, England.

Gilad, O., Yun, S., Andree, K. B., Adkison, M.A., Zlotkin, A., Bercovier, H., Eldar, A., \& Hedrick, R.P. (2002). Initial characterization of koi herpesvirus and development of a polymerase chain reaction assay to detect the virus in koi, Cyprinus carpio koi. Dis. Aquat. Org., 48, 101-108.

Gray, W.L., Mullis, L., LaPatra, S.E., Groff, J.M., \& Goodwin, A. (2002). Detection of koi herpesvirus DNA in tissues of infected fish. Journal of Fish Diseases, 25: 171-178. doi: 10.1046/j.13652761.2002.00355.x

Hardjosubroto, W. (1994). Aplikasi pemuliabiakan ternak di lapangan. Jakarta: PT Grasindo Indonesia.

Harvey, B. \& Carolsfeld, J. (1993). Induced breeding in tropical fish culture. Ottawa, Canada, IDCR. 144 pp.

Kusriani, Widjanarko, P., \& Rohmawati, N. (2012). Uji pengaruh pestisidan Diazinon $60 \mathrm{EC}$ terhadap rasio konversi pakan dan pertumbuhan ikan mas (Cyprinus carpio L.). Jurnal Penelitian Perikanan, 1(1): 36-42.

Macbeth, G.M. \& Palmer, P.J. (2011). A novel breeding programme for improved growth in barramundi Lates calcarifer (Bloch) using foundation stock from progeny-tested parents. Aquaculture, 318, 325-334.

Noor, R.R. (2000). Genetika ternak. Jakarta: Penebar Swadaya, $200 \mathrm{hlm}$.

Pang, J.C., Feng-ying, G., Mai-xin, L., Xing, Y., Huaping, Z., \& Xiao-li, K. (2013). Major histocompatibility complex class IIA and IIB genes of Nile tilapia (Oreocrhomis niloticus): Genomic structure, molecular polymorphism and expression patterns. Fish and Shelfish Immunology, 34, 486-496.

Park, I.S. (2002). Induction of ovulation by HCG, LHRHa and carp pituitary in Rhynchocypris oxycephalus (Sauvage and Dabry). Asian Fisheries Science, 15, 387393.

Rakus, K.L., Wiegertjes, G.F., Jurecka, P., Walker, P.D., Pilarczyk, A., \& Irnazarow, I. (2009). Major histocompatibility $(\mathrm{MH})$ class II B gene polymorpishm influences disease resistance of common carp (Cyprinus carpio L.). Aquaculture, 288, 44-50.

Subowo. (1993). Imunobiologi. Bandung: Angkasa, 232 hlm.

Sunarto, Rukyani, A., \& Itami, T. (2005). Indonesian experience on the outbreak of koi herpes virus in koi and carp (Cyprinus carpio). Bull. Fish. Res. Agen. Supplement, 2, 15-21.

Tave, D. (1993). Genetic for fish hatchery managers. $2^{\text {nd }}$ ed. AVI. Publishing Company. Inc. Connecticut.

Tave, D. (1996). Selective breeding programmes for medium-sized fish farm. FAO technical papers. Rome.

Warwick, J.W., Astuti, M., \& Hardjasubroto, W. (1995). Pemuliabiakan ternak. Yogyakarta: Gajahmada University Pres.

Yudiarto, S., Arief, M., \& Agustono. (2012). Pengaruh penambahan atraktan yang berbeda dalam pakan pasta terhadap retensi protein, lemak dan energi benih ikan sidat (Anguilla bicolor) Stadia Elver. Jurnal IImiah Perikanan dan Kelautan, 4(2), 135-140.

Zhou, F., Zhongdian, D., Yong, F., Tongming L., Yongqing, Z., Xiangshan, J., Weiyun, C., Jiao, Z., \& Hui, W. (2013). Molecular cloning, genomic structure, polymorphism and expression analysis of major histocompatibility complex class II B gene of nile tilapia (Oreochromis niloticus). Journal Aquaculture, 372-375, 149-157. 